\title{
A LIQUIDAÇÃO DA DÍVIDA DO AMAZONAS
}

O Decreto-lei n: 6.763 , de 3 de agôsto de 1944, que autorizé a União a liquidar dívidas do Estado do Amazonas, resultou de is anteprojeto apresentado pelo Sr. Luís Simões Lopes à Comiss de Estudos dos Negócios Estaduais. Em longa e fundamenta exposição de motivos, foram postos em equação e discutidos, cc proficiência e senso realista, os aspectos sociais, econômicos e $\mathrm{F}$ líticos da questão. A divulgação desta peça, que a Revista c Serviço Público inseriu integralmente no fascículo de setembri último (Ano VII, vol III, n.o 3, p. 158-169), dispensa qualquer menção neste comentário dos motivos de ordem geral que levaram - Govêrno a baixar o citado decreto-lei. Sòmente os aspectos jurídicos mais relevantes serão focalizados.

2. A ingerência da União na vida financeira dos Estados está prevista na Constituição, nos arts. 8\%, parágrafo único, e 9\%, letra $d$.

Na primeira hipótese, "o Estado que, por três anos consecutivos, não arrecadar receita suficiente à manutenção dos seus serviços, será transformado em território até o restabelecimento de sua capacidade financeira".

Essa transformação em território, não implicando em reforma de caráter permanente, da "atual divisão política e territorial" (Const., art. $3 .^{\circ}$ ), far-se-á mediante lei ordinária. A administração

IV - Quando fôr conveniente a menção do dispositivo da legislação ordinária em que tiver fundamento o ato, o preâmbulo será:

O Presidente da República, usando da atribuição que lhe confere o artigo 180 (ou 74, letra...) da Constituição, e nos têrmos do artigo o da Lei (ou decreto-lei; ou do decreto) n. ... de . de . de.t.

Decreta :

V Os "consideranda", quer nos decretos-leis, quer nos decretos, deverão

ser reduzidos a indispensável, no caso de não ser possível evitálos's,
Posteriomente, en longa exposição de motivos, aprovada pelo Chefe do Estado, D. A.S. P. recomendou a indicação do art. 14 da Constituíçăo, e nâo do art 180, oma todos os decretos-leis expedidos, nos limites das dotaçöes orçamentária, sôbre a organização do Govêrno da Administração Federal, o comando e a organização das fốrças armadas (Rev. Fot., vol. 94, pág. 603). 
do Estado ficará sujeita a regime de leis especiais que o Conselho Federal votará, atendendo às peculiaridades de cada caso (Const., arts. 35 e 53 ).

Prevê, na segunda hipótese, o texto constitucional, a intervenção federal para reorganizar as finanças do Estado que suspender, por mais de dois anos consecutivos, o serviço de sua dívida fundada, ou que, passado um ano do vencimento, não houver resgatado empréstimo contraído com a União", cabendo à Câmara dos Deputados decretá-la (art. 9., parágrafo único).

3. Sendo de notória insolvência a situação financeira do Estado do Amazonas, a União poderia optar por qualquer das hioóteses aludidas. Preferiu, porém, a segunda, isto é, usar dos poleres que a intervenção já decretada no art, 178, parágrafo único, ie confere, em combinação com a faculdade de legislar prevista 1 art. 180, ambos da Constituição.

Assim, foi no exercício legítimo da outorga constitucional de tervir na vida financeira dos Estados, que a União baixou o ecreto-lei n. 6.763 .

Não havendo, por outro lado, o texto constitucional estabeleıdo limitações específicas à tarefa de "reorganizar as finanças do ¿stado", fica à discrição do legislador ordinário preferir a que melhor consulte ao bem público e ao interêsse coletivo.

4. A União poderia estabelecer tantos planos quantos fôssem necessários, separando ou englobando dívidas, a fim de atender à sua origem, natureza $e$ antiguidade.

A condição de que a dívida seja anterior a 31 de dezembro de 1939 (art. 1.\%), para que se possa enquadrar no plano-de liquidação, é, pois, matéria de simples conveniência administrativa, que não pode sofrer efítica de natureza jurídica.

5. A liquidação dos créditos far-se-á com os descontos previstos no art $4^{\circ}$. Este critério coloca em pé de igualdade todos os credodres de igual quantia, sejam os créditos quirografários ou privilegiados.

Em se tratando de dívida pública, que se deve resgatar integralmente, qualquer que seja a natureza do título ou o instrumento do crédito, não seria conveniente estabelecer tratamento especial em benefício de alguns credores, como se procede nas falências, concordatas ou concursos de credores de insolváveis, pessoas físicas ou jurídicas de direito privado.

6. Sòmente o principal é resgatável, excluídos os juros mor tórios, segundo dispóe o art. 5. . Também os cessionários, herdeiros ou sucessores, não poderão fazer valer, na forma do direitc comum, a condição do credor originário, em relação a cada um dos créditos. Opera-se a fusão de todos êles para o efeito da aplicação da taxa de descontos. 
7. No art. $70^{\circ}$, a lei estabelece, como requisito essencial para a liquidação da dívida, que o credor passe quitação de todo o crédito, ficando, assim, vedada e sem objeto qualquer ação judicial futura para o recebimento de diferença proveniente de abatimento dos quantitativos originários.

O reconhecimento da dívida pela Comissão especial é, também, imprescindivel. Estabeleceu a lei, neste particular, providência idêntica à existente com relação à Câmara do Reajustamento Econômico.

Como informou o Ministro CAstro Nunes, a propósito da autonomia da dita Câmara, no Rec. Extr. n. ${ }^{\circ}$ 6.723, julgado pelo Supremo Tribunal Federal em 26-7-43 e publicado no Diário da Justiça de 15-2-44, p. 991, a "União só consente em tomar a seu cargo a metade da dívida do agricultor se essa obrigação resultat para ela de decisão daqueles árbitros legais", isto é, dos membro componentes da Câmara. No mesmo sentido, é o parecer do Pró curador Geral da República, GabRIEL DE Resende PASSOS, n Apel. Cíve1 n. ${ }^{\circ}$ 7.535, Revista Forense, vol. 91, p. 120.

8. Como a União se propõe a liquidar dívida alheia, deter mina o art. $8^{\circ}$ que, na verificação dos créditos, se observe a legislação vigente. A edição de normas especiais viria dificultar a tarefa da Comissão e tornar incerta e discutível dívidas contraídas de acôrdo com as prescrições do direito comum. Com a remissão feita, evitar-se-ão surprêsas e complicações para as partes interessadas.

Não seria também prudente que a Comissão, que é delegada da União, pudesse reconhecer dívidas ou transigir, sem autorização expressa e formal do Govêrno do Estado devedor. Caso contrário, teria a lei deixado margem a futuras controvérsias entre a União e - Estado sôbre a legitimidade dos pagamentos feitos sem esta cautela. O resgate de divida prescrita foi vedado. $E$ ' verdade que, pelo direito comum, o devedor pode renunciar à prescrição. Mas a dívida prescrita é dívida extinta que só por liberalidade se paga. Se não há numerário para resgate das dívidas exigíveis, não seria lógico permitir tal procedimento.

A União, que tomou a si o encargo de pagar dívidas alheias, quer que estas sejam insuscetíveis de qualquer controvérsia. Se houver, portanto, renúncia de prescrição, não terá o credor direito de habilitar-se à liquidação prevista na lei. Pode, ainda, acontecer que o critério de reconhecimento da dívida por parte do Estado não seja aceito pela Comissão. Neste caso prevalecerá a decisão desta, como mandatária da União pagadora (art. 7:0).

9. O plano de resgate não é compulsório. Se o credor não quiser habilitar-se a receber, mediante as condiçóes previstas na 
lei, pode aguardar o momento oportuno para fazer valer o seu direito, na forma das leis vigentes. Fica, apenas, deferido o pagamento de seu crédito para depois que a União houver sido paga (art. 17).

A União, ao efetuar os pagamentos, sub-roga-se no direito dos credores originários.

Em competição com os demais credores, o crédito da União, qualquer que seja a sua origem, é considerado privilegiado para todos os efeitos de direito e deverá ser pago preferencialmente.

Transportou o legislador para a lei especial um princípio do direito comum. O parágrafo único do art. 60 do Decreto-lei número 960 , de 17-12-38, dispõe que "a divida da União prefere a qualquer outra, em todo o território nacional", e não está sujeita a concurso de credores, nem a habilitação de crédito em falência, concordata ou inventário.

Finalmente, os privilégios e preferências estabelecidas em favor dos créditos da União sempre foram consignados nas leis ordinárias, não havendo, neste particular, obstáculo constitucional.

Carlos Medeiros Silva 